http://jmscr.igmpublication.org/home/ ISSN (e)-2347-176x ISSN (p) 2455-0450 crossref DOI: https://dx.doi.org/10.18535/jmscr/v8i1.37

\title{
A Case control Study on Thyroid abnormalities in Chronic Kidney Disease patients
}

\author{
Authors \\ Dr Jyotshna Potta ${ }^{1 *}$, Dr Mallikarjun ${ }^{2}$, Dr Ranganadha Rao $\mathbf{R}^{3}$, Dr Vijaya Lakshmi ${ }^{4}$ \\ ${ }^{1}$ Postgraduate, Department of General Medicine, GEMS \\ ${ }^{2}$ Professor of General Medicine, GEMS \\ ${ }^{3,4}$ Assistant Professor of General Medicine, GEMS \\ *Corresponding Author
}

Jyotshna $\mathbf{P}$

\section{Introduction}

Chronic kidney disease is one of the major health problems in India. In India prevalence of chronic kidney disease $17.2 \%$. Kidneys are involved in the metabolism and elimination of thyroid hormone. The decline in renal function is accompanied by changes in the synthesis, secretion, metabolism, an elimination of thyroid hormone. Thyroid hormones are necessary for growth and development as well as maintenance of water and electrolytes.

\section{Aims of the Study}

- To study the thyroid abnormalities in patients with chronic kidney disease

- Estimating thyroid hormone levels i.e. T3, T4 and TSH in patients of CKD

- Estimation of serum urea and creatinine for selection of test subjects.

\section{Materials and Methods}

This is a case control study carried out GEMS hospital, department of general medicine, Srikakulam, Andhra Pradesh from January 2018 to November 2018. The study comprised of 60 male patients with diagnosis of chronic kidney disease evaluated for thyroid dysfunction. Known chronic kidney disease patients subjected to morning sample blood was drawn after $12 \mathrm{hrs}$ fasting and estimated serum creatinine, blood urea, $\mathrm{t} 3$, t4, TSH for every patient including cases and controls.

Inclusion Criteria cases:

a. Aged between 40-70 years

b. Having history of chronic kidney disease

c. Serum creatinine $>5.5 \mathrm{mg} / \mathrm{dl}$ and blood urea $>55 \mathrm{mg} / \mathrm{dl}$

d. Dipstick test positive for protein with symptoms of chronic renal failure.

\section{Exclusion Criteria}

- Patients with diabetic nephropathy

- Patients on treatment with estrogen, corticosteroids, sulphonylurea, phenobarbitones \& b-blocker

- Female \& children's are excluded from the study. 


\section{Statistical Methods}

a. Results on continuous measurements are presented on mean \pm SD (min-max)

b. Results on categorical measurements are presented in number (\%).

c. Significance is assessed at $5 \%$ level of significance.

d. Fisher Exact test has been used to find the significance of study parameters on categorical scale between two or more groups.

e. Pearson correlation has been used to find the correlation of serum creatinine in cases with $\mathrm{t} 3$, $\mathrm{t} 4$ and TSH

\section{Statistics and Results}

Distribution of age in years between two groups

\begin{tabular}{|c|c|c|c|c|}
\hline $\begin{array}{c}\text { Age in } \\
\text { years }\end{array}$ & $\begin{array}{c}\text { Cases } \\
\text { No }\end{array}$ & $\begin{array}{c}\text { Cases } \\
\%\end{array}$ & $\begin{array}{c}\text { Controls } \\
\text { No }\end{array}$ & $\begin{array}{c}\text { Controls } \\
\%\end{array}$ \\
\hline $44-49$ & 12 & 20.0 & 14 & 23.3 \\
\hline $50-54$ & 18 & 30.0 & 18 & 30.0 \\
\hline $55-59$ & 16 & 26.7 & 20 & 33.3 \\
\hline 60 \& above & 14 & 23.3 & 8 & 13.3 \\
\hline Total & 60 & 100.0 & 60 & 100.0 \\
\hline
\end{tabular}

Comparison of study parameters in cases and controls (mean $\pm \mathrm{SD})$

\begin{tabular}{|l|c|c|c|}
\hline $\begin{array}{l}\text { Study } \\
\text { variables }\end{array}$ & Cases & controls & P value \\
\hline Blood urea & $96.23 \pm 12.24$ & $28.47 \pm 8.40$ & $<0.001$ \\
\hline S creatinine & $5.83 \pm 0.69$ & $1.09 \pm 0.17$ & $<0.001$ \\
\hline T3 & $81.67 \pm 15.07$ & $111.96 \pm 10.17$ & $<0.001$ \\
\hline T4 & $5.80 \pm 0.50$ & $8.36 \pm 0.46$ & $<0.001$ \\
\hline Tsh & $4.81 \pm 0.38$ & $3.02 \pm 0.79$ & $<0.001$ \\
\hline
\end{tabular}

Comparison of $\mathrm{T}_{3}$ in cases and controls

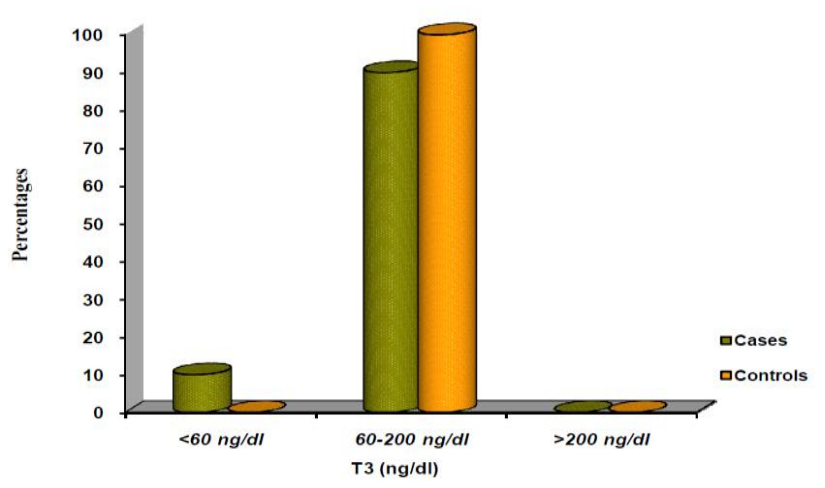

Comparison of $\mathrm{T}_{4}$ in cases and controls
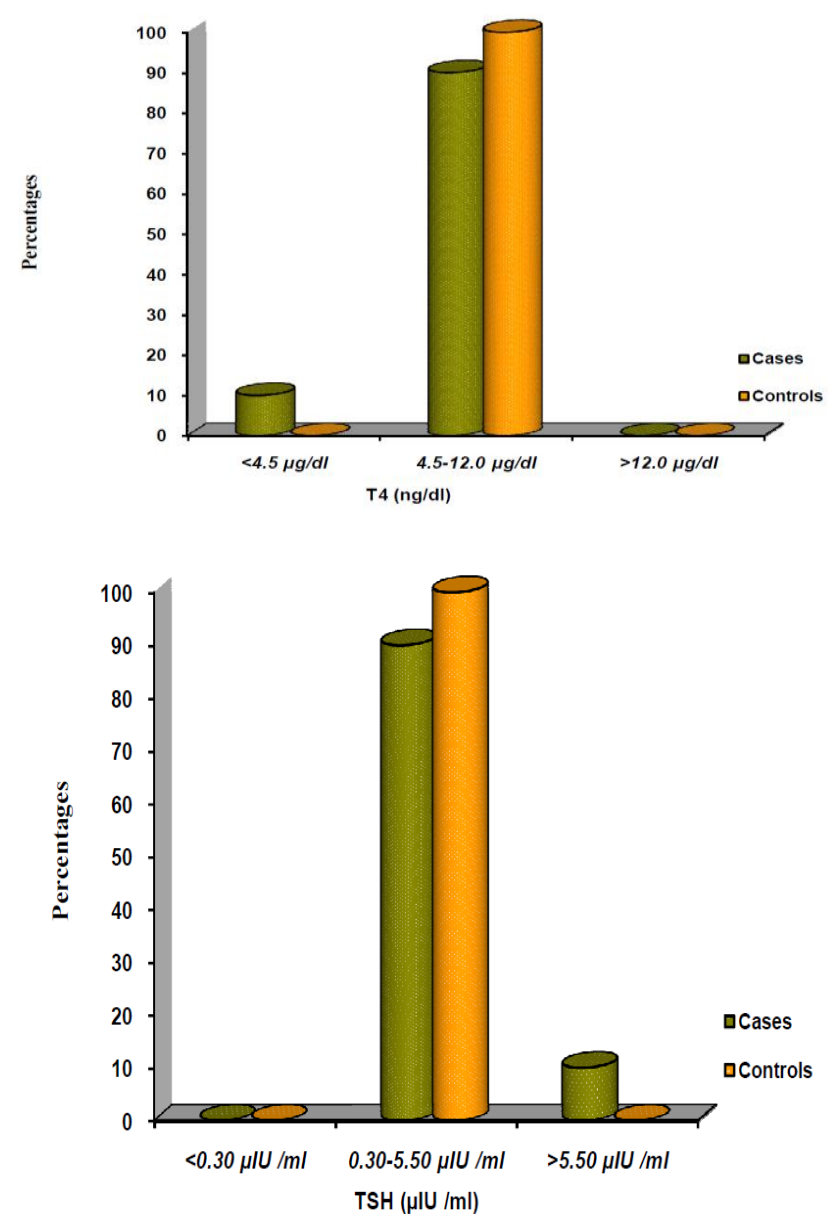

Incidence of hypothyroidism and hyperthyroidism

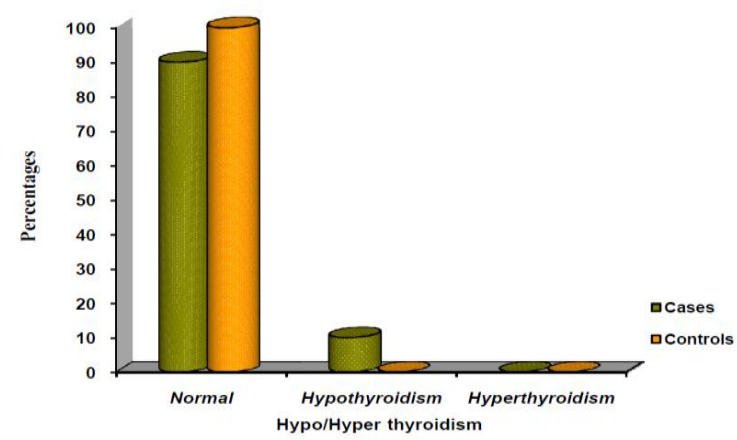

a. The incidence of hypothyroidism is $10 \%$ in chronic kidney disease cases when compared to controls.

b. $\mathrm{P}$ value is 0.237 which is positive correlation between CKD and hypothyroidism.

c. There is no hyperthyroidism found in both cases and controls. 
Incidence of hypothyroidism in relation to severity of renal failure in cases

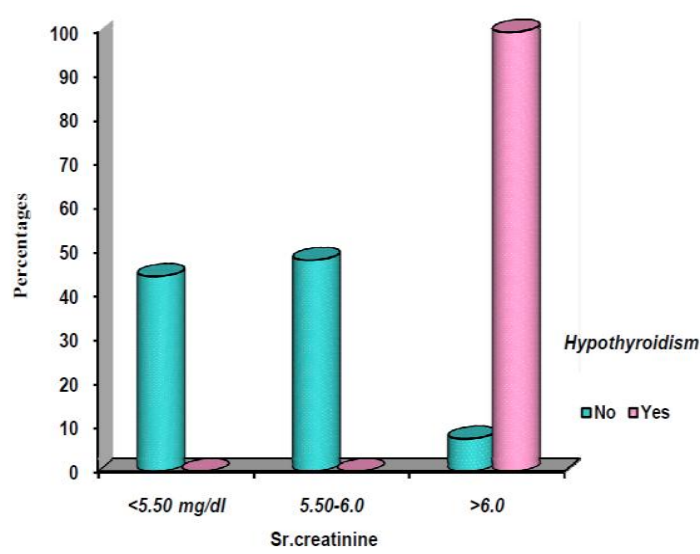

Incidence of hypothyroidism in relation to severity of renal failure in cases

\begin{tabular}{|l|c|c|}
\hline Sr.Creatinine & $\begin{array}{c}\text { No Clinical } \\
\text { Hypothyroidism }\end{array}$ & $\begin{array}{c}\text { Clinical } \\
\text { Hypothyrodism }\end{array}$ \\
\hline$<5.50 \mathrm{mg} / \mathrm{dl}$ & $24(44.4 \%)$ & 0 \\
\hline $5.50-6.0$ & $26(48.1 \%)$ & 0 \\
\hline$>6.0 \mathrm{mg} / \mathrm{dl}$ & $4(7.4 \%)$ & $6(100.0 \%)$ \\
\hline Total & $54(100.0 \%)$ & $6(100.0 \%)$ \\
\hline
\end{tabular}

Pearson correlation of serum creatinine and thyroid hormones

\begin{tabular}{|l|c|c|}
\hline pair & Correlation & P value \\
\hline Sr creatinine vs T3 & -0.791 & $<0.001$ \\
\hline Sr creatinine vs T4 & -0.631 & $<0.001$ \\
\hline Sr creatinine vs TSH & 0.479 & $<0.001$ \\
\hline
\end{tabular}

Incidence of hypothyroidism is significantly associated with Sr.creatinine $>6.0 \mathrm{mg} / \mathrm{dl}$ with $\mathrm{p}=0.002$ which is statistically significant.

\section{Discussion}

The mean of blood urea and serum creatinine is high in cases when compared to the controls. All patients in cases are positive for frank proteinuria by urine dip stick test. The mean of T3 and T4 in all 60 cases is decreased when compared to controls even though most of them are within the normal range. CKD is associated with higher prevalence of hypothyroidism, both overt and subclinical, but not with Hyperthyroidism. In this study the findings are comparable with the previous study showing decreased levels of T3, T4 and Free T3 in uremic and heamodialysis patients. In this study patients with low T3, T4 and free T4 showed high $\mathrm{TSH}$ suggesting maintenance of pituitary thyroid axis.

Endocrine function is diffusely abnormal in patients of uremia and chronic kidney disease secondary to Diminished renal degradation of polypeptides, Receptor dysfunction, Changes in protein binding and Abnormal endocrine feedback control.

Patients in late chronic kidney disease often appear hypothyroid \& Thyroid function tests are abnormal. Despite normal free levothyroxine, free tri-iodothyronine levels are low and binding of levothyroxine to thyroxine binding globulin is diminished .

\section{Conclusion}

Mean of T3, T4 decreases TSH increases significantly in cases compare to controls. Among them $10 \%$ of CKD (cases) patients are hypothyroid where as its $0 \%$ in controls. There is no hyperthyroidism both in cases \& controls. TSH increases as T3, T4 decreases which suggests the maintenance of pituitary thyroid axis. The levels of thyroid profile i.e. T3, T4 decreases TSH increases as severity of renal failure increases (i.e., as serum creatinine increases).

\section{References}

1. Santosh Varughese and Georgi Abraham, Chronic Kidney Disease In India Clin J Am Soc Nephrol 13: 802-804, 2018.

2. $\mathrm{P}$ Iglesias and $\mathrm{J} \mathrm{J}$ Di'ez. Thyroid dysfunction and kidney disease. European Journal of Endocrinology (2009) $160503-$ 515. 